\title{
Materials Challenges for Advanced Combustion and Gasification Fossil Energy Systems
}

\author{
S. SRIDHAR, P. ROZZELLE, B. MORREALE, and D. ALMAN \\ This special section of Metallurgical and Materials Transactions is devoted to materials chal- \\ lenges associated with coal based energy conversion systems. The purpose of this introductory \\ article is to provide a brief outline to the challenges associated with advanced combustion and \\ advanced gasification, which has the potential of providing clean, affordable electricity by \\ improving process efficiency and implementing carbon capture and sequestration. Affordable \\ materials that can meet the demanding performance requirements will be a key enabling tech- \\ nology for these systems.
}

DOI: $10.1007 / \mathrm{s} 11661-011-0627-\mathrm{x}$

(C) The Minerals, Metals \& Materials Society and ASM International (outside the USA) 2011

\section{INTRODUCTION}

THE 2010 Energy Outlook Assessment by the U.S. Energy Information Administration (EIA) forecasts that, while nonfossil energy use will grow rapidly, fossil fuels will still provide 78 percent of total U.S. energy use in $2035 .{ }^{[1]}$ However, converting fossil fuels to energy is a major contributor to green house gas $(\mathrm{GHG})$ emissions. According to the U.S. Environmental Protection Agency, in 2006, the total GHG emissions in the United States were estimated at 7100 million metric tons $\mathrm{CO}_{2}$ equivalent. ${ }^{[2]}$ This estimate included $\mathrm{CO}_{2}$ emission as well as other GHGs such as methane, nitrous oxide, and other hydrofluorocarbons. Of this amount, about $53 \mathrm{pct}$ (3800 million metric tons) of the GHG emissions were attributed to stationary fossil fuel combustion sources. Eighty three percent of the stationary sources are from emissions from generating electricity. ${ }^{[2]}$ The U.S. Department of Energy (U.S. DOE) is actively engaged in research and development efforts focusing on carbon capture and storage (CCS) as a means to reduce the emission of $\mathrm{CO}_{2}$ from fossil fueled power plants. Simply, this concept comprises capturing (or separating) the $\mathrm{CO}_{2}$ from the power plant and storing the $\mathrm{CO}_{2}$ in an underground geological formation for permanent sequestration. A key aspect of this strategy is the development of advanced combustion and gasification technologies that are more efficient and produce effluent streams that facilitate the capturing of $\mathrm{CO}_{2}$.

S. SRIDHAR, POSCO Professor, is with the Department of Materials Science and Engineering, Carnegie Mellon University, Pittsburgh, PA 15213, and is also with the National Energy Technology Laboratory, U.S. Department of Energy, Pittsburgh, PA 15236. Contact e-mail: sridhars@andrew.cmu.edu P. ROZZELLE, Program Manager, is with the Office of Clean Energy Systems, U.S. Department of Energy, Washington, DC 20585. B. MORREALE, Acting Materials Science and Engineering Focus Leader, is with the National Energy Technology Laboratory, U.S. Department of Energy. D. ALMAN, Division Director, is with the Materials Performance Division, National Energy Technology Laboratory, U.S. Department of Energy.

Manuscript submitted January 11, 2011.

Article published online February 16, 2011
Higher efficiency boilers and turbines require less fuel and produce electricity, and thus emit less greenhouse gases. Today, the most advanced steam plants are only about 35 pct efficient and operate with steam conditions approaching $893 \mathrm{~K}\left(620^{\circ} \mathrm{C}\right)$ and $20 \mathrm{MPa} \cdot{ }^{[3,4]}$ The U.S. DOE goal of a 48 pct efficient steam plant will require ultra-supercritical (USC) steam conditions, approaching $1033 \mathrm{~K}\left(760{ }^{\circ} \mathrm{C}\right)$ and $35 \mathrm{MPa}$. Operating at these conditions will result in a 20 to 25 pct decrease in $\mathrm{CO}_{2}$ emissions (Figure 1). ${ }^{[3]}$ Identifying cost-effective materials that can operate for long periods of time at extreme temperatures and pressures is a major challenge for implementing USC systems.

The combustion process is the highly exothermic chemical reaction of the carbon and hydrogen within the coal in the presence of excess oxygen (Eqs. [1] and [2], respectively). In a typical air-blown coal-fired power generation system, the flue gas consists mostly of nitrogen $\left(\mathrm{N}_{2}\right)$ and $\mathrm{CO}_{2}$. Separating $\mathrm{CO}_{2}$ from this flue gas stream is challenging because of the dilute concentration (13 to $15 \mathrm{vol}$ pct) of the $\mathrm{CO}_{2}$ in the flue gas. Oxyfuel or Oxy-fired, where the combustion reactions take place in oxygen-enriched environments, combustion products are primarily $\mathrm{CO}_{2}$ and $\mathrm{H}_{2} \mathrm{O}$. By condensing the $\mathrm{H}_{2} \mathrm{O}$, the $\mathrm{CO}_{2}$ can easily be captured for permanent geological sequestration. There are technological challenges to oxyfuel systems, including costeffective oxygen production as well as understanding the impact of the change of combustion environment on the performance of the boiler's materials of construction.

$$
\begin{gathered}
\mathrm{C}+\mathrm{O}_{2}=\mathrm{CO}_{2} \quad \Delta H=-283 \mathrm{~kJ} / \mathrm{mol} \\
\mathrm{H}_{2}+{ }_{1} / 2 \mathrm{O}_{2}=\mathrm{H}_{2} \mathrm{O} \quad \Delta \mathrm{H}=-242 \mathrm{~kJ} / \mathrm{mol}
\end{gathered}
$$

Alternatively, in the gasification process carbon-containing material, such as coal, react with steam and controlled amounts of air or oxygen, at high pressures and temperatures to form a synthesis gas (or syngas) composed primarily of carbon monoxide and hydrogen. Along with the preceding combustion reactions (Eqs. [1] and [2]), the chemical reactions listed subsequently 


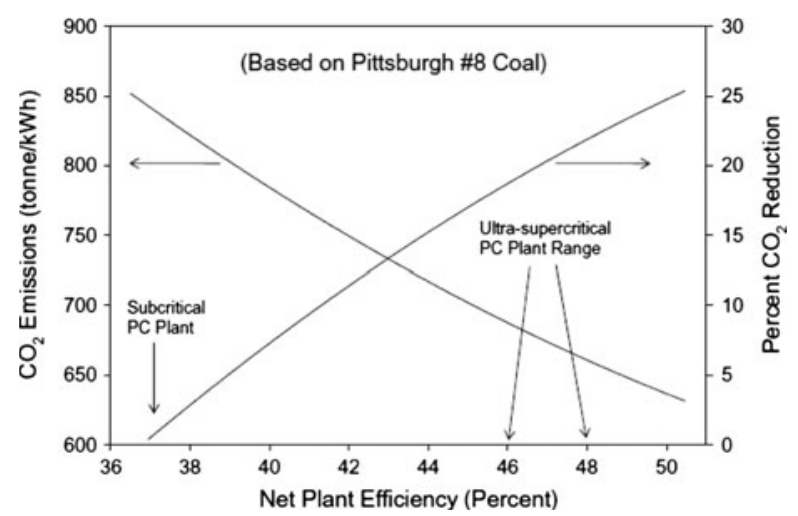

Fig. 1-Effect of efficiency on $\mathrm{CO}_{2}$ emission for steam generating pulverized coal. ${ }^{[3]}$

(Eqs. [3] through [8]) dominate the gasification process. Gasification is an efficient technology for processing solid carbon based fuels into synthesis gas to make electric power through integrated gasification combine cycle (IGCC) plants. This technology is an important option in future energy production because of its efficiency and because environmental pollutants such as $\mathrm{SO}_{2}$ and mercury are easily captured in the process; further, since gasification is a closed process, the $\mathrm{CO}_{2}$ produced in the exhaust gas can be easily captured for permanent geological sequestration. Materials challenges exist in gasification with the development of a reliable refractory liner material that can withstand the gasifier environment: elevated temperatures $1548 \mathrm{~K}$ and $1848 \mathrm{~K} \quad\left(1275{ }^{\circ} \mathrm{C}\right.$ to $\left.1575^{\circ} \mathrm{C}\right)$, pressures $(2.07$ to $6.90 \mathrm{MPa}$ ), and the presence of corrosive materials.

$$
\begin{gathered}
\mathrm{CO}+1 / 2 \mathrm{O}_{2}=\mathrm{CO}_{2} \quad \Delta \mathrm{H}=-283 \mathrm{~kJ} / \mathrm{mol} \\
\mathrm{C}+\mathrm{CO}_{2}=2 \mathrm{CO} \quad \Delta \mathrm{H}=+172 \mathrm{~kJ} / \mathrm{mol} \\
\mathrm{C}+\mathrm{H}_{2} \mathrm{O}=\mathrm{CO}+\mathrm{H}_{2} \quad \Delta \mathrm{H}=+131 \mathrm{~kJ} / \mathrm{mol} \\
\mathrm{C}+\mathrm{H}_{2}=\mathrm{CH}_{4} \quad \Delta \mathrm{H}=-75 \mathrm{~kJ} / \mathrm{mol} \\
\mathrm{CO}+\mathrm{H}_{2} \mathrm{O}=\mathrm{CO}_{2}+\mathrm{H}_{2} \quad \Delta \mathrm{H}=-41 \mathrm{~kJ} / \mathrm{mol} \\
\mathrm{CH}_{4}+\mathrm{H}_{2} \mathrm{O}=\mathrm{CO}+3 \mathrm{H}_{2} \quad \Delta \mathrm{H}=+206 \mathrm{~kJ} / \mathrm{mol}
\end{gathered}
$$

The numerous materials challenges associated with advanced coal combustion and coal gasification technologies are briefly described subsequently in Section I-A.

\section{A. Materials Challenges for Advanced Coal Combustion Technologies}

Coal is used to create almost half of all the electricity generated in the United States, and with few exceptions, this electricity is generated through traditional coal combustion to produce steam. The EIA estimates that, based on U.S. coal consumption for 2008, the U.S. recoverable coal reserves represent enough coal to last $\sim 234$ years. ${ }^{[1]}$ However, the EIA projects that U.S. coal consumption will increase at about 0.6 pct per year until 2030. If that growth rate continues into the future, the U.S. recoverable coal reserves would be exhausted in about 146 years if no new reserves are added. In any event, for the foreseeable future, domestically abundant coal will continue to be fuel for producing electricity. The statistics are similar worldwide. However, as stated previously, one of the major by-products of coal combustion is $\mathrm{CO}_{2}$, which is a GHG. Advanced USC and oxyfuel combustion systems offer the ability to reduce and control emissions from conventional airblown coal combustion and the identification of costeffective materials is needed for development and deployment of these technologies.

Today the most advanced plants operate at steam conditions of $866 \mathrm{~K}\left(593{ }^{\circ} \mathrm{C}\right)$. New plants are being commissioned that operate up to $893 \mathrm{~K}\left(620^{\circ} \mathrm{C}\right)$. Research efforts are underway worldwide to increase steam temperatures and improve the efficiency of coal combustion plants. The U.S. DOE program has the most ambitious goal of steam at $1033 \mathrm{~K}\left(760^{\circ} \mathrm{C}\right)$ and $35 \mathrm{MPa}$. This is compared to the European program's aim of $923 \mathrm{~K}\left(650^{\circ} \mathrm{C}\right)$ (and $973 \mathrm{~K}\left(700{ }^{\circ} \mathrm{C}\right)$ over the next decade). In any event, improved materials will be needed to satisfy these goals. The increase in steam temperature results in numerous materials challenges with respect to mechanical performance, steam side oxidation resistance, and fireside corrosion resistance, as well as issues associated with alloy weldability and formability. ${ }^{[4]}$ The remainder of this section briefly outlines materials issues associated with USC steam and oxyfuel combustion plants.

As a general reference, subcritical conditions refer to steam at pressures less than $21 \mathrm{MPa}$. Supercritical conditions refer to steam at greater than $21 \mathrm{MPa}$ pressure and at a temperature between $808 \mathrm{~K}$ and $838 \mathrm{~K}\left(535^{\circ} \mathrm{C}\right.$ and $\left.565{ }^{\circ} \mathrm{C}\right)$. Ultra-supercritical conditions refer to steam pressure greater than $21 \mathrm{MPa}$ and steam temperature between $849 \mathrm{~K}$ and $948 \mathrm{~K}\left(576^{\circ} \mathrm{C}\right.$ and $675^{\circ} \mathrm{C}$ ), and advanced ultra-supercritical conditions refer to steam pressure greater than $21 \mathrm{MPa}$ and steam temperature above $948 \mathrm{~K}\left(675^{\circ} \mathrm{C}\right)$. It should be emphasized that these are steam temperatures; consequently, metal temperatures will exceed steam temperatures. Steam temperatures of $1033 \mathrm{~K}\left(760{ }^{\circ} \mathrm{C}\right)$ can correspond to metal temperatures of $1088 \mathrm{~K}\left(815^{\circ} \mathrm{C}\right)$ or higher.

The increase in operating temperature for USC boilers will result in the use of greater quantities of austenitic steels and nickel alloys than in today's most advanced boilers. Components operating at the highest temperatures will need to be constructed out of $\mathrm{Ni}$ base alloys. However, as the boiler section temperature decreases, materials of construction will transition to less expensive iron based alloys. Table I lists candidate alloy compositions for the different boiler components.

The need for more expensive Ni alloys as materials of construction is due to the need for creep resistance ${ }^{[4-7]}$ Figure $2^{[7]}$ compares the creep rupture life for Ni alloys to ferritic and austenitic steels for boiler tube applications. The temperature limit for advanced ferritic alloys is $898 \mathrm{~K}\left(625^{\circ} \mathrm{C}\right)$ and for austenitics is $948 \mathrm{~K}\left(675^{\circ} \mathrm{C}\right)$. Nickel alloys will be required for operating temperatures 
Table I. Candidate Alloys for USC Boiler Applications ${ }^{[7]}$

\begin{tabular}{lll}
\hline Alloy & \multicolumn{1}{c}{ Nominal Composition } & \multicolumn{1}{c}{ Application* } \\
\hline H230 & 57Ni-22Cr-14W-2Mo-La & P, SH/RH tubes \\
IN740 & 50Ni-25Cr-20Co-2Ti-2Nb-V-Al P, SH/RH tubes \\
CCA617 & 55Ni-22Cr-.3W-8Mo-11Co-Al & P, SH/RH tubes \\
HR6W & 43Ni-23Cr-6W-Nb-Ti-B & SH/RH tubes \\
Super 304H & 18Cr-8Ni-W-Nb-N & SH/RH tubes \\
Save 12 & 12Cr-W-Co-V-Nb-N & P \\
T92 & 9Cr-2W-Mo-V-Nb-N & WW tubes \\
T23 & 2-1/4Cr-1.5W-V & WW tubes
\end{tabular}
wall.

$\mathrm{P}=$ pipe, $\mathrm{SH}=$ superheater, $\mathrm{RH}=$ reheater, and $\mathrm{WW}=$ water-

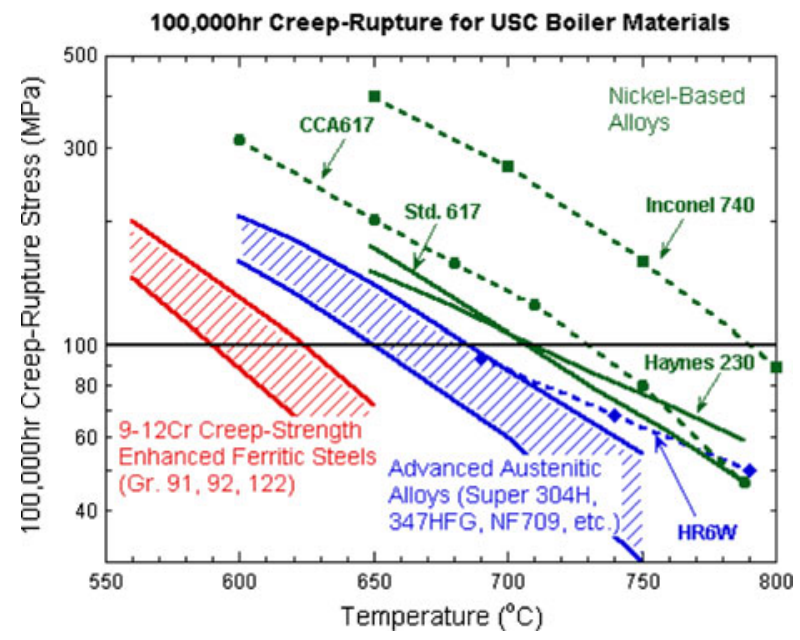

Fig. 2 - Comparison of creep behavior of advanced alloys under consideration for applications in ultra-supercritical steam boiler applications. ${ }^{[7]}$

above $948 \mathrm{~K}\left(675^{\circ} \mathrm{C}\right)$. Research as part of the U.S. DOE Boiler Materials for Ultra-Supercritical Coal Power Plant indicates that the age-hardenable nickel base superalloy INCONEL* 740 appears to have the

*INCONEL is a trademark of Special Metals Corporation, New Hartford, NY.

strength necessary for meeting the U.S. DOE program's target steam temperature and pressure.

Steam side oxidation resistance is also a major issue for USC boilers. ${ }^{[8]}$ In a power plant, there are three major detriments to steam side oxidation: (1) loss of wall thickness that can compromise structural integrity; (2) excessive oxide scale growth that can act as an insulating barrier to heat transfer, causing localized overheating and subsequent loss of structural integrity of the tube; and (3) spalling of the oxide scales that can lead to plugging tubes (at bends) resulting in localized overheating and loss of structural integrity of the tube or erosion in the steam turbine if the spalled oxide is entrained in the steam path and enters the turbine. For these reasons, it is important that a thin, tightly adherent oxide scale forms on the inner boiler tube walls. However, scale growth and spalling are exacerbated at the higher USC temperatures. Viswantathan et al. ${ }^{[8]}$ summarized the steam oxidation behavior for a variety of alloys under consideration for USC boiler applications. While alumina forming alloys typically are more oxidation resistant than chromia forming alloys at elevated temperatures, chromia alloys are preferred for application due to cost considerations, as these alloys are typically easier to form and join. The general trend is that increasing $\mathrm{Cr}$ content will increase oxidation resistance.

Historically, fireside corrosion has limited boiler operations to about $811 \mathrm{~K}\left(538^{\circ} \mathrm{C}\right)$. Throughout the 1950 s and 1960s, boilers were designed and built to operate at steam temperatures above this temperature. Materials were available to meet the strength requirements; however, these materials proved susceptible to fireside corrosion, specifically corrosion of the final superheater and reheater outlet tubes. The accelerated material wastage affected most materials of construction available at the time, and consequently, steam temperatures were reduced to $811 \mathrm{~K}\left(538{ }^{\circ} \mathrm{C}\right)$. Fireside corrosion (often referred to as ash corrosion) is a very complex problem and is dependent on the ash composition of the coal. Ash corrosion is dependent on the sulfur, alkali, and chlorine content of the coal and is especially an issue in boilers burning low rank feeds. Control of fireside corrosion to acceptable levels is of paramount importance in the development of advanced coal-fired boilers. ${ }^{[4,8-10]}$

Simply, for iron based alloys, ash corrosion occurs when molten liquid iron-trisulfides forms on the metal surface beneath coal ash that has deposited in the tube's surface. Typically, there is an incubation period in which the corrosion rate is low, as the protective oxides scales slowly dissolve into the solid $(\mathrm{K}, \mathrm{Na})_{2} \mathrm{SO}_{4}$ deposits in the presence of $\mathrm{SO}_{3}$. Introduction of $\mathrm{Fe}$ into the $(\mathrm{K}, \mathrm{Na})_{2} \mathrm{SO}_{4}$ deposit forms $2(\mathrm{~K}, \mathrm{Na})_{3} \mathrm{Fe}\left(\mathrm{SO}_{4}\right)_{3}$, which has a melting point below the metal temperature. The formation of molten phase promotes rapid dissolution of the metal's oxide scale and a subsequent accelerated corrosion rate and material wastage. The onset of significant corrosive attack occurs at temperatures around $813 \mathrm{~K}\left(540{ }^{\circ} \mathrm{C}\right)$ and increases with increasing temperatures. The complex iron-trisulfides are unstable above $973 \mathrm{~K}\left(700{ }^{\circ} \mathrm{C}\right)$. Therefore, ash corrosion is most pronounced at $953 \mathrm{~K}$ to $973 \mathrm{~K}\left(680^{\circ} \mathrm{C}\right.$ to $\left.700{ }^{\circ} \mathrm{C}\right)$; above $973 \mathrm{~K}\left(700{ }^{\circ} \mathrm{C}\right)$, corrosion decreases significantly. At $923 \mathrm{~K}\left(650^{\circ} \mathrm{C}\right)$, it has been found that nickel alloy is of interest, as boiler tubes do not afford any improvement in resistance to ash corrosion compared to iron alloys of interest. ${ }^{[4]}$ Under USC operating conditions, type-II hot corrosion may be problematic for $\mathrm{Ni}$ alloys, as $1033 \mathrm{~K}\left(760{ }^{\circ} \mathrm{C}\right)$ is high enough that formation of molten ash will not occur. In this case, the operative mechanism is oxidation and sulfidation occurring beneath the ash deposit on the metal surface. Consequently, coating may be required to protect boiler tubes from the fireside environment. ${ }^{[4,11]}$

\section{B. Materials Challenges for Gasification Technologies}

Through gasification, carbonaceous feedstock such as coal, petroleum coke (petcoke), and biomass is con- 
verted into synthesis gas (syngas), which includes carbon monoxide, hydrogen, carbon dioxide, water, and methane. Also included will be nitrogen, argon, sulfur species, ammonia, and halides. In general, the process is carried out by reacting the organic feedstock with a fuel-rich atmosphere. The resultant syngas can, after further processing, be used to generate electric power ${ }^{[12-18]}$ through, e.g., combustion or electrochemical conversion in fuel cells. Syngas production can also be integrated with petroleum refining ${ }^{[19]}$ and can be used to produce feedstock for the production of liquid fuels and chemicals, ${ }^{[20]}$ substitute natural gas, ${ }^{[21]}$ fertilizer, ${ }^{[22]}$ and hydrogen. ${ }^{[23]}$

Gasification presents several advantages as an option for the generation of power from low cost solid fuels such as coal. Among these are inherently low emissions of sulfur and nitrogen oxides, the potential to co-fire low cost opportunity fuels, and the adaptability to CCS to achieve near-zero air emissions.

\section{Types of technologies}

Commercial gasification systems are broadly available in three configurations.

(1) The countercurrent fixed bed gasifier in which steam and oxygen/air are blown in a countercurrent manner through a bed of the feedstock, which needs to have sufficient mechanical strength and bed permeability. The configuration of a fixed bed is not unlike that of the blast furnace. The resulting ash can be solid or a molten slag depending on the fuel characteristics and system operating parameters.

(2) The fluid bed gasifier, in which the feedstock is fluidized in the steam and oxygen/air stream. In order to maintain the bed inventory in a properly fluidized state, this type of system is operated at a relatively low temperature and the ash may be removed dry.

(3) The entrained flow gasifier, operated at very high temperatures and pressures using oxygen, water (or steam), and pulverized solid feedstock. The high temperatures enable a variety of feedstock and the resulting ash is molten.

Regardless of the use for the syngas, further processing will be required downstream of the gasification system. This processing will require cooling, particulate removal, and acid gas removal. Gas cooling will be frequently associated with steam generation, especially in the case of power generation using integrated gasification combined cycle (IGCC) technology. Particulate removal is required to remove entrained solids (i.e., flyash) from the syngas stream, and acid gas removal will remove sulfur species. For synthetic fuel or chemical production, or for an IGCC process employing CCS, shifting of the syngas (i.e., the water gas reaction) is also a likely requirement. Example process flow sheets for several gasification systems can be found among References 12 through 23 .

\section{Limitations and opportunities}

While the gasification process can present several advantages, there are constraints to these systems that are related to materials. These challenges can result in reliability constraints, with attendant economic penalties. These materials challenges can be related to materials used in plant equipment, but frequently will also be influenced by materials derived from fuel components and their interaction with plant components. Examples of these interactions can include wear in components that prepare gasifier fuel, gasifier refractory consumption, fouling of syngas cooling equipment, and erosion and corrosion of components that handle flyash laden process water. These items can cause significant financial constraints to a plant using gasification technology, which in turn justifies fundamental research into their causes. However, it can be seen that materials research of this type must focus on more than just the materials from which plant components are fabricated. Knowledge of the properties of the fuel and its products resultant from gasification is also essential in gaining improved understanding of their interactions with plant components.

Limiting this discussion to fuel-derived products of the gasification process, the carbon and hydrogen in solid fuel fed to a gasifier will be largely converted to the gaseous components in the syngas, although a portion of the carbon will leave as unreacted char. Solid fuels also contain ash-forming inorganic species (i.e., mineral matter), which can be removed from the system as slag or solid ash products. Further limiting the discussion to slagging gasifiers, the fuel mineral matter can be expected to undergo phase changes due to its properties and system conditions. Some of these mineral components will liquefy at gasifier temperatures $(T=1573 \mathrm{~K}$ to $1873 \mathrm{~K}\left(1300{ }^{\circ} \mathrm{C}\right.$ to $\left.1600{ }^{\circ} \mathrm{C}\right), P=2.75 \mathrm{MPa}$, and $\log \left(P_{\mathrm{O} 2}\right)=-9$ to -7$)^{[24]}$ and may coalesce into a stream that leaves the gasifier as slag. Some of the mineral matter will also leave the system entrained with the product syngas as flyash. The flyash flow from the gasifier can also contain the majority of the unconverted combustibles from the system. ${ }^{[13]}$

Slag in the gasifier will be in contact with gasifier wall materials, which can include refractories and metals. Flyash leaving the gasifier with the syngas can be expected to contact gas handling components including syngas coolers. In both cases, the nature of the interaction between component materials and those derived from the fuel can cause reliability constraints.

Fuel constituents that do not leave the system as gaseous species will leave with two streams: slag and flyash. Two challenges related to fuel inorganic components bear specific mention. In the case of the flyash, fouling of syngas coolers has been reported by multiple projects ${ }^{[13,15,16,25]}$ using different gasification technologies. With respect to slag, its viscosity can cause flow problems or it can cause degradation of gasifier refractories. Where the fuel mineral matter will not produce a suitable slag viscosity, flux additions may be dictated and the resultant change to slag properties may change the nature of the interaction with the gasifier refractory liner.

There has been some published work on the nature of entrained flow gasifier flyash, focused on the cooler fouling problem as well as possible uses for the material. 
The Cool Water Project ${ }^{[12]}$ reported syngas cooler fouling issues. Brooker ${ }^{[26]}$ published analyses of solids collected from the Cool Water plant, as well as those for the corresponding fuel, which was bituminous coal from Utah. Several analyses were presented for solids associated with deposits on syngas cooling equipment. The flyash showed some enrichment in iron content over both the fuel ash and the slag.

That work also presented some detailed analysis of a cross section of a deposit on the radiant syngas cooler. A $50-\mu \mathrm{m}$-thick layer of iron sulfide was found nearest to the metal. The next later was $500-\mu \mathrm{m}$ thick and was composed of iron sulfide embedded with flyash and scale particles. While the iron content decreased with distance from the metal, at a distance of $25 \mathrm{~mm}$, the iron content of the deposit was still enriched over that of the fuel ash. Additionally, fluorite and halite were found in the deposits, and while the halogen contents of the coal were low, it was noted that recycling of the process water (contacting the syngas) to the plant feed caused a buildup of fluorine and calcium in the feed slurry.

Brooker and $\mathrm{Oh}^{[27]}$ examined flyash and deposits associated with operation of the Texaco gasification pilot plant in Montebello, California, attempting to identify a mechanism for FeS formation that was leading to deposits. Deposits were taken from a transfer line from the radiant cooler of the pilot plant and compared to the flyash. Also presented for comparison was a slag analysis. The fuel was Pittsburgh Seam coal, and the iron contents of the deposits and flyash were roughly comparable. However, the sulfur contents found in the deposits were as much as 3 times higher than the sulfur contents found in the slag or flyash. That work suggested a mechanism where an iron oxy-sulfide compound can migrate to the surface of a siliceous ash matrix. The Brooker and Oh work also suggested that FeS could be formed by reaction of iron species in the fuel and $\mathrm{H}_{2} \mathrm{~S}$ in the gas phase.

Font et al. ${ }^{[28]}$ examined flyash samples from the Puertollano IGCC plant. Sulfur was found to be present in the material primarily as sulfide, and iron, largely present as $\mathrm{Fe}^{2+}$, was primarily present in amorphous aluminosilicates (such as suggested by Brooker and $\mathrm{Oh}^{[27]}$ as a source of iron for reaction with $\mathrm{H}_{2} \mathrm{~S}$ in the gas phase). However, sulfides, including FeS, were found to be the main crystalline phases in the flyash.

The slag-refractory interaction has also been the subject of several studies. The mechanisms of slagrefractory interactions causing refractory degradation include chemical dissolution, mechanical erosion, and structural spalling. ${ }^{[30]}$ The nature of the mineral matter was found to vary with different fuels, imparting different chemical and physical properties to the slag. High chrome oxide refractory liners are used to line gasifiers because of their superior resistance to attack. $^{[14,18,19]}$ Through evaluations of slag/refractory interaction by isothermal cup-type experiments, Rawers et al. ${ }^{[29]}$ found a spinel $(\mathrm{Al}, \mathrm{Cr}, \mathrm{Fe})_{3} \mathrm{O}_{4}$ phase on the refractory side of the coal slag/high chrome refractory interface in addition to dissolution of $\mathrm{Cr}$ into the coal slag.

\section{The pertinent properties of the molten slag}

The processes that involve slags and fluxes in the metallurgical industry as well as in the slagging gasifiers are dependent on thermodynamics, kinetics, and fluid flow. In order to tailor the slags to enhance their intended roles, while eliminating the unwanted side effects, the physical properties that govern the rate of the various processes have to be identified and the composition modified in the appropriate way. The difficulty in implementing this lies in the fact the properties are interconnected; thus, compositionally changing a property may alter other properties. The way to solve this problem is to understand the common link that determines the properties, which is the structure. Although it is clear that the properties are related to structure, ${ }^{[20]}$ the mechanisms by which these relations work and their interdependence is largely unknown. By gaining information on the structure, we can establish its influence on physical properties, viz. (1) the compositional and thermal dependence of the physical properties and (2) the relation between the properties. Thermophysical properties are all in one way or another connected to (1) the degree of polymerization and (2) the size and shape of the polymeric units. Generally, industrial slags and fluxes contain $\mathrm{SiO}_{2}, \mathrm{Me}_{x} \mathrm{O}$ (metal oxides), and, depending on the slag, additional compounds such as $\mathrm{Al}_{2} \mathrm{O}_{3}$, $\mathrm{CaF}_{2}$, and $\mathrm{P}_{2} \mathrm{O}_{5}$. The ratio $\mathrm{SiO}_{2} / \mathrm{Me}_{x} \mathrm{O}$ is an indication of the degree of polymerization. This is because each $\mathrm{Me}_{x} \mathrm{O}$ is considered to break a bond of a threedimensional network of tetrahedral units of $\mathrm{SiO}_{4}{ }^{4-}$ or $\left(\vdots \mathrm{Si}-\mathrm{O}^{-}\right)$by supplying an additional oxygen and charge compensating the electron at the broken bond with the cation. When the ratio of $\mathrm{SiO}_{2} / \mathrm{Me}_{x} \mathrm{O}$ is 2 , each tetrahedral unit has one unshared corner and the structure is expected to resemble that of an endless sheet; ${ }^{[20]}$ at a ratio of 1 , the structure resembles endless chains. At higher $\mathrm{Me}_{x} \mathrm{O}$ contents, the network breaks down further to form rings and then to discrete units of silica compounds. While $\mathrm{P}_{2} \mathrm{O}_{5}$ can easily accommodate itself by substituting $\mathrm{P}$ for $\mathrm{Si}$ in the silica network $\left(\mathrm{PO}_{4}{ }^{4-}\right), \mathrm{Al}_{2} \mathrm{O}_{3}$ is amphotheric and accommodates itself in the silica network in silica rich melts as $\mathrm{AlO}_{4}{ }^{5-}$ but acts as a network breaker in melts with low silica contents. Fluorides are generally thought to break the network $^{[31]}$ according to the reaction $(: \mathrm{Si}-\mathrm{O}-\mathrm{Si}:)+$ $\left(\mathrm{F}^{-}\right)=\left(\vdots \mathrm{SiO}^{-}\right)+(\mathrm{F}-\mathrm{Si}:)$, but there still is uncertainty concerning (1) the individual effect of the cation, (2) whether fluorine acts as a network breaker also at basic compositions, and (3) whether a unit of $(\mathrm{F}-\mathrm{Si}$ : $)$ is equivalent to a unit of $\left(: \mathrm{Si}-\mathrm{O}^{-}\right)$with respect to physical properties such as viscosity and thermal conductivity.

The structural parameters, (1) the size of Si-polymeric units, (2) the way in which cations are incorporated and their ability to move, and (3) the interionic bonds between Si-polymeric units and between Si-polymeric units and cations, basically decide the bulk thermophysical properties (density, crystallization temperature, viscosity, thermal/electrical conductivity, enthalpy, and heat capacity). A structural study, therefore, is inevitable before reliable models can be constructed to estimate properties from compositions and temperature. As 
indicators of structures in slags, the following parameters can be used:

$$
\text { Basicity }=\frac{\text { pctCaO }+1.5 \text { pctMgO }}{\text { pct } \mathrm{SiO}_{2}+0.84 \text { pct } \mathrm{P}_{2} \mathrm{O}_{5}}
$$

A high basicity would be indicative of a low degree of polymerization. A more quantitative definition is the number of nonbridging oxygen per tetrahedral coordinated atom, NBO/T ratio. ${ }^{[32]}$

$$
\frac{\mathrm{NBO}}{T}=\frac{2\left(X_{\mathrm{Na}_{2} \mathrm{O}}+\mathrm{K}_{2} \mathrm{O}+\mathrm{Li}\right)}{X_{\mathrm{SiO}_{2}}}
$$

A lower $\mathrm{NBO} / \mathrm{T}$ ratio is indicative of a lower degree of polymerization.

The two critical properties for a smooth operation of a gasifier are, perhaps, viscosity and crystallization temperature. The most evident connection between structure and property is that of viscosity. Viscosities of polymeric slags are usually Newtonian and are often expressed in an Arrhenius type of equation: $\eta=\eta_{0}$. $\exp \left(-E_{\text {act }} /(\mathrm{R} T)\right)$, were $E_{\text {act }}$ is related to the energy required to move one silica unit with respect to another one. Consequently, the activation energy is expected to drop as the silica units get smaller, since smaller units have a fewer number of negative charges and, therefore, fewer number bonds that need to be broken. Several models have been developed for predicting viscosity from chemical compositions and temperature. However, the performance of the various models varies depending on the range of viscosity covered, and the current understanding of the structure of slags is not enough to construct a model that will encompass a wider range in viscosity. A "round robin" project was carried out with the purpose of establishing the accuracy and reliability of various models used to estimate viscosities of industrial slags. It was found that the model proposed by Mills et al. ${ }^{[33]}$ was suitable for predicting viscosities of coal slags giving a relative difference between computed and measured values of 19 pct, which is in fact better than the experimental repeatability. The thermodynamics and kinetics of crystallization behavior are directly linked to the degree of polymerization of the melt and is not at all well understood. A high viscosity (due to polymerization) is usually indicative of (1) a higher solidification temperature ${ }^{[31]}$ and (2) enhanced glass forming tendency. The development of confocal microscopy ${ }^{[34]}$ offers a new and exciting method to investigate the structural changes of the slag that lead to either a glassy or crystalline structure.

\section{Hydrogen separation membranes}

Membranes that can efficiently and economically remove hydrogen produced from the gasification processes have the potential to increase the overall efficiency of the gasification process by a few percentage points. Although hydrogen selective membranes can be fabricated from numerous classes of materials, including ceramics, polymers, metals, and combinations thereof, metal membranes have received the greatest attention in recent years. Metal membranes, typically a Pd alloy employed as a free standing film or a thin film supported on a highly permeable substrate, have the potential to produce infinitely pure hydrogen via a solution-diffusion process. In this process, gas phase hydrogen is adsorbed on the surface exposed to the high pressure hydrogen, where the catalytic nature of the surface rapids produces atomic hydrogen available for transport through the crystalline structure of the metal. The atomic hydrogen migrates to the low pressure surface of the membrane, recombines to molecular hydrogen, and desorbs into the gas phase. This unique transport property for hydrogen gives the ability of dense metal membrane systems to produce low pressure, infinitely pure hydrogen while leaving a highly concentrated, high pressure stream $\mathrm{CO}_{2}$ steam ready for co-sequestration.

Additionally, studies suggest that the integration of membrane and reaction processes within the gasification process can have technoeconomic benefits. For example, in practice, the water-gas shift reaction is carried out in multiple thermocatalytic reactors with interstage cooling in an effort to maximize the conversion of $\mathrm{CO}$. However, an integrated water-gas shift membrane reactor to the slightly exothermic reaction can eliminate the need for numerous reactors, interstage cooling, high steam-CO ratios, and even catalysts.

However, dense metal membrane technology is still in the $\mathrm{R} \& \mathrm{D}$ phase, and several materials issues need to be addressed prior to its widespread acceptance and implementation. Pd-alloy based membranes have shown susceptibility to degradation by syngas laden contaminants. For example, a pure palladium membrane exposed to $1000 \mathrm{ppm} \mathrm{H}_{2} \mathrm{~S}\left(\mathrm{P}_{\mathrm{H} 2 \mathrm{~S}} / \mathrm{P}_{\mathrm{H} 2} \sim 1 \times 10^{-3}\right)$ for 120 hours at temperatures consistent with the WGS operation forms a significant corrosion scale (up to 30 $\mu \mathrm{m})$. Conversely, $\mathrm{Pd}$ alloyed with $\mathrm{Cu}$ or $\mathrm{Au}$ exposed to similar conditions significantly retards sulfide formation; however, it exhibits near zero hydrogen flux. Therefore, for dense metal membrane technologies to be successful, as with the majority of structural materials for service in extreme environments, materials need to be identified that can not only withstand trace contaminants associated with gasification, but also possess the characteristics required for hydrogen transports (catalytically active, highly permeable, and selective for hydrogen).

\section{This special section}

Four articles are included in this special section related to the development of more reliable structural materials for fossil power systems. Two are focused on ceramics. In the article by Eakins, Jayaseelan, and Lee, processing parameters for $\mathrm{ZrB}_{2-}-\mathrm{SiC}$ are evaluated for usage in ultra-high-temperature application, where temperatures may exceed $2273 \mathrm{~K}\left(2000{ }^{\circ} \mathrm{C}\right)$. The second article by Bennett and Kwong presents recent research carried out on the failure of chrome-oxide based refractory lining for slagging gasifiers. The article by Yanar, Helminiak, Taylor, Meier, and Pettit discusses the effects of processing route and exposure on YSZ based thermal barrier coatings. Finally, the article by Yamamoto, Brady, Santella, Bei, Maziasz, and Pint presents recent results from the development of austenitic alumina forming alloys. 


\section{REFERENCES}

1. U.S. Energy Information Agency: "Annual Energy Outlook," Report No. DOE/EIA-0383(2010), Apr. 2010.

2. D. Deel: Carbon Sequestration Atlas of the United States and Canada, 2nd ed., National Energy Technology Laboratory, U.S. Department of Energy, Pittsburgh, PA, 2008.

3. R. Viswanathan, A.F. Armor, and G. Booras: Power, Apr. 2004, pp. 42-49.

4. R. Viswanathan, K. Coleman, and J. Shingledecker: "Boiler Materials for Ultrasupercritical Coal Power Plants-Phase I Final Summary Report,' US DOE Report No. DE-FG26-01NT41175, U.S. Department of Energy, Feb. 15, 2007.

5. R. Viswanathan and W. Bakker: J. Mater. Eng. Perform., 2001, vol. 10, pp. 81-95.

6. R. Viswanathan, J.F. Henry, J. Tanzosh, G. Stanko, and J. Shingledecker: J. Mater. Eng. Perform., 2005, vol. 14, pp. 281-92.

7. R. Viswanathan, J. Shingledecker, J. Hawk, and S. Goodstine: Paper presented at 2nd Int. ECCC Conf. on Creep \& Fracture in High Temperature Components-Design \& Life Assessment, Dübendorf, Switzerland, Apr. 21-23, 2009.

8. R. Viswanathan, J. Saver, and J.M. Tanzosh: J. Mater. Eng. Perform., 2006, vol. 15, pp. 255-74.

9. W. Bakker, G. Stanko, J. Blough, W. Sietz, and S. Niksa: Mater. High Temp., 2007, vol. 24, pp. 275-84.

10. J.L. Blough, G. Stabko, W.T. Bakker, and J.B. Brooks: Corrosion 2000, NACE, Houston, TX, 2000, paper no. 00250.

11. S. Goodstine and J.C. Nava: Paper presented at Proc. 29th Int. Conf. on Coal Utilization and Fuel Systems, Clearwater, FL, Apr. 18-25, 2004.

12. Cool Water Coal Gasification Program and Radian Corporation: "Cool Water Coal Gasification Program: Final Report," Report No. EPRI GS-6806, Project 1459, Palo Alto, CA, Dec. 1990.

13. Tampa Electric Company: "Tampa Electric Integrated Gasification Combined Cycle Project," Project Performance Summary, Clean Coal Technology Demonstration Program, U.S. Department of Energy, DOE/FE-0469, 2004.

14. Tampa Electric Company: "Tampa Electric Polk Power Station Integrated Gasification Combined Cycle Project," Final Technical Report No. DE-FC21-91MC27363, Aug. 2002.
15. Wabash Energy Limited: "Wabash River Coal Gasification Repowering Project," Final Technical Report No. DE-FC2192MC29310, Aug. 2000.

16. Elcogas: "Puertollano a Clean Coal Gasification Power Plant," Feb. 2001.

17. T. Ono: Paper presented at Proc. Gasification Technologies Council Meeting, Oct. 2003.

18. J.T.G.M. Eurlings and J.E.G. Ploeg: Paper presented at Proc. Gasification Technologies Council Conf., Oct. 2001.

19. A.K. Rhodes: Oil Gas J. Au, 1996, Aug., pp. 31-34.

20. P. van Nierop, H.B. Erasmus, and J. W. van Zyl: Paper presented at Proc. Gasification Technologies Council Conf., Oct. 2000.

21. U.S. Department of Energy: "Practical Experience Gained During the First Twenty Years Operation of the Great Plains Gasification Plant and Implications for Future Projects," Apr. 2006.

22. C.R. Ferguson, J.S. Falsetti, and W.P. Volk: Paper presented at National Petroleum Refiners Association Annual Meeting, Mar. 1999.

23. D. Grey and G. Tomlinson: "Hydrogen from Coal," Mitretek Technical Paper No. MTR-2002-31, 2002.

24. K. Kwong, A. Petty, J. Bennett, R. Krabbe, and H. Thomas: Appl. Ceram. Technol., 2007, vol. 4 (6), pp. 503-13.

25. M. Kanaar: Paper presented at Gasification Technologies Council Conf., Oct. 2002.

26. D. Brooker: Fuel, 1992, vol. 72 (5), pp. 665-70.

27. D. Brooker and M.S. Oh: Fuel Process. Technol., 1995, vol. 44, pp. 181-90.

28. O. Font, X. Querol, F.E. Huggins, J.M. Chimenos, A.I. Fernandez, S. Burgos, and F.G. Pena: Fuel, 2005, vol. 84, pp. 1364-71.

29. J. Rawers, J. Kwong, and J. Bennett: J. Mater. High Temp., 1999, vol. 16 (4), pp. 219-22.

30. W.E. Lee and S. Zhang: Int. Mater. Rev., 1999, vol. 44 (3), pp. 77-104.

31. F.D. Richardson: Physical Chemistry of Melts in Metallurgy, Academic Press, New York, NY, 1974, vol. 1, p. 81.

32. K.C. Mills: ISIJ Int., 1993, vol. 33, pp. 148-55.

33. K.C. Mills, L. Chapman, A.B. Fox, and S. Sridhar: Scand. J. Metall., 2001, vol. 30 (6), pp. 396-404.

34. J. Nakano, S. Sridhar, T. Moss, J. Bennett, and K.-S. Kwong: Energy Fuels, 2009, vol. 23 (10), pp. 4723-33. 